\title{
LICENSING THE USE OF SPECIAL COLLECTIONS MATERIALS
}

THIS ARTICLE HAS BeEN written to assist special collections administrators who want to establish a fee policy and schedule for the publication (in any media or format) of original materials in their charge. The article examines the history of special collections' approaches to this practice, offers a rationale for charging fees, discusses relevant copyright issues, and offers model policies and fee schedules.

The article grew out of the work of an ad hoc committee of the Rare Books and Manuscripts Section of the Association of College and Research Libraries. The Licensing and Reproduction of Special Collections Committee had been asked to "create a reasoned and articulate defense of libraries' right to charge licensing fees for commercial uses of their materials."

For the sake of simplicity, the more generic term "library" and its plural are used throughout the article, but it should be understood that the principal audiences being addressed are special collections and archives.

\section{Background}

Historically, libraries have allowed scholars relatively free use of the intellectual property physically embodied in their collections. Compensation, if any, usually took the form of an acknowledgment and, perhaps, a free copy of the work in which the intellectual property appeared. Libraries fundamentally operated on a barter system in 
which intellectual property was traded for publicity or the more tangible commodity of a free book. This world is described in James Thorpe's survey of common practice, The Use of Manuscripts in Literary Research; an environment in which, only occasionally, "a library may ask for a permissions fee if the work is a commercial product intended to yield a financial return."1

The barter system worked satisfactorily for decades for a variety of reasons. Most of the intellectual property going out of libraries was for scholarly use in dissertations, academic journal articles, or university press monographs published by genuinely not-for-profit entities. In this environment, free use was subsidized by adequate budgetary support for libraries and was a somewhat literal manifestation of the academic principle supporting the free exchange of ideas. But the environment in which the barter system survived has changed dramatically.

Libraries remain dedicated to scholarship. But in fulfilling this mission, they take on the responsibility of administering large, and frequently costly, acquisition, preservation, cataloging, and educational and outreach programs, often in a budgetary environment that is unstable and in competition with simultaneous priorities. As noted in the executive summary of a 1998 ARL survey of special collections libraries: "There is a gap between the relative weight of special collections in a library's holdings... and the share of material expenditures it receives... and some special collections may be more vulnerable to budget cuts than is generally supposed."

The nature of scholarly publishing also has changed significantly. University presses are more aware of market pressures that blur the

1. James Thorpe, The Use of Manuscripts in Literary Research (Chicago: Modern Language Association, 1974, revised 1979), 27.

2. Judith M. Panitch, Special Collections in ARL Libraries: Results of the 1998 Survey Sponsored by the ARL Research Collections Committee (Washington, D.C.: Association of Research Libraries, 2001), 8. 
line between scholarly and commercial publication. Mary Murrell, a senior editor at Princeton University Press, notes that "this change in perspective-from the customer as institution to the customer as individual-has forced university presses to become more commercially minded, more competitive, and more aggressive." Elaine M. Stainton, senior editor at Harry N. Abrams, argues that university presses "as 'non-profit' organizations ... enjoy tax advantages that commercial presses do not," that "their work can be supported by grants," and that their own sponsoring universities have made it clear that they need to become self-supporting. "In other words, the university press ... is no longer a 'service department' of its parent institution. It has become a profit center." 4

Furthermore, as noted by Marie Malaro in A Legal Primer on Managing Museum Collections, the Internet has dramatically hastened the commodification of original materials and heightened the role of libraries as content providers:

advances in computer technology have spawned an expanding multimedia industry hungry for what is known as "existing content." To many in the business, museum/library collections are veritable cookie jars of desirable images and textual material .... At the same time, museums/libraries that want to reach broader audiences are publishing their collections in new multimedia products and are establishing their presence on-line.... 5

Such strong external and internal demand on library resources has sparked a reconsideration of publication policies and procedures. At issue is a library's assertion of certain rights that, by tradition, govern an owner's ability to manage use of owned physical property.

3. Mary Murrel, "Is Literary Studies Becoming Unpublishable?" PML A 116, no. 2 (Mar. 2001): 394.

4. Elaine M. Stainton, "Photo Reproduction Fees and Designations: Three Modest Proposals," 26 November 2001. Available online from http://www.indiana.edu/\%7Eaah/newsphoto.html. 5. Marie Malaro, A Legal Primer on Managing Museum Collections, 2nd ed. (Washington, D.C.: Smithsonian Institution Press, 1998). 


\section{Copyright Considerations}

There is no question that a library can charge publication fees if it has been able to secure, along with a donation or bequest of a physical collection, attendant copyrights. Often the specific intent of the donor is that revenues gained from the transfer of rights will go toward the preservation, cataloging, and promotion of the collection. Copyrights may have been assigned in lieu of establishing a cash endowment designed to support such activities. In such an instance, a library is well within the parameters of the donor's wishes to exploit its copyrights to support general maintenance of the collection.

This is true, too, when rights are expressly assigned as part of a purchase agreement. It is probable that a significant part of the purchase price may have been for the rights themselves and not merely for the physical embodiment of them. In such a case, the library may feel that it has a responsibility to recoup some of the money spent on rights by charging publication fees to be applied toward preservation, cataloging, and educational outreach.

If a library is unable to acquire the copyrights along with the physical collection, it may still be able to secure certain usage rights above and beyond the right to exhibit and display that comes with title transfer. Additional rights a library may want to try to secure through a license agreement with the copyright holder at the time of acquisition may include: ${ }^{6}$

- the right to publish text or images in exhibition materials such as catalogues and promotional copy;

- the right to publish copyright-protected materials in institutionally generated educational publications; 
- the right to license use of copyright-protected materials to third parties (i.e., the library's patrons);

- the right to post images on the owning institution's Web site;

- the right to create derivative works such as postcards, posters and calendars;

- the right to create merchandise, such as T-shirts and tote bags.

\section{Physical Ownership Considerations}

The rationale for charging fees is less clear-cut when a library owns a physical collection, but not the intellectual property rights embodied in it. With some limitations, copyright law gives copyright owners the exclusive right to reproduce, adapt, distribute, publicly perform, and publicly display their works and to control performances of sound recordings by audio transmission. When a library, in its capacity as owner of a physical original, assesses a publication fee above and beyond any a copyright holder might charge, the reasons for doing so need to be clearly distinguished from the exclusive rights afforded copyright holders.

When the work in question is in the public domain (i.e., no longer enjoys copyright protection of any sort), resistance to a library's charging a fee for the publication of that work grows more vocal. Stephen Fishman, in a section of his book The Public Domain titled "The Looting of the Public Domain," argues against "the widespread use of contracts [i.e. licenses] to restrict how the public can use public domain materials" through the imposition of restrictions on subsequent use. It is interesting that he singles out archives and historical societies as

7. Stephen Fishman, The Public Domain: How to Find \& Use Copyright-free Writings, Music, Art \& More (Berkeley, Calif.: Nolo, 2001), 2-10. 
sources where the public can still obtain copies of public domain works without signing a license. More recently, the Bureau of the Comité International de Paléographie Latine has initiated an appeal for libraries and museums to limit publication fees for not-for-profit, scholarly studies to the actual photographic reproduction costs. For libraries and museums to charge above and beyond these, the Comité argues, is to "betray their essential duty: to support scholarly research on their collections." 8

It can be argued that what the Comite is really asking for is not mere support, but subsidization. Scholars, copyright holders, and publishers-the three entities accustomed to being the only participants in the publication equation - need to be educated that choice alone, not law, has kept many libraries from charging publication fees and from participating fully in the movement of scholarly information from repository to reading public. But to make themselves a viable and accepted fourth party, libraries will have to confront and overcome such objections as those summarized above.

Here, a value-added argument is persuasive. Library activities that build value onto an archive may include rehousing, environmental controls, conservation treatments, preservation reformatting, and cataloging-all of which maximize an archive's useful life. As Georgia Harper, intellectual property counsel of the University of Texas System, has written:

These services are expensive. Publication fees charged to offset such expenses are not within the scope of copyright. Instead, they are a legitimate prerogative of management of an archive.

Were the same works unprotected by copyright, a repository would still need to charge fees to users of the works because 
the cost of maintaining the archive, not the status of their protection under copyright law, forms the basis of the fees. Fees are charged, pursuant not to law but to a repository's need to conduct a service that needs to operate in the black rather than in the red.

Special collections value and support the sharing of their holdings with the public and a publication fee policy and structure is not intended to discourage such sharing. Rather, the intent is physically and fiscally to manage collections so that they continue to exist in excellent condition and to be available ... when today's copyrights will play absolutely no part in their value at all. ${ }^{9}$

An echo of this view comes from Amalyah Keshet, head of visual resources at the Israel Museum, Jerusalem: "If ... museums ... do not earn income (in many ways, not just by photo licensing ...), we cannot preserve, research, interpret, display, and publish the works of art in our care. You won't have museums to go to to see p[ublic] d[omain] works of art." ${ }^{10}$

Whatever persuasive arguments are used, in the absence of a written assignment of rights, a clear fair use, or a clear indication that copyrights have expired, a library may still authorize use of materials in its possession by means of what Penny Cobey terms a "quitclaim permissions letter." In template form, it reads:

The Library is pleased to grant non-exclusive permission to [licensee] to use and reproduce the Library's image of [describe] in [describe product]. The fee for this permission is $\$$ _ . The Library offers this permission only with regard to rights held by the Library. The Library does not covenant, warrant or

9. Internal university communication.

10. Amaylah Keshet posting to the cni-copyright listserv, 13 April 1999, on the subject of fine art reproductions. 
represent that it is the exclusive holder of all rights in the WORK and [licensee] promises that it will obtain any and all additional licenses and permissions that may be necessary before using or reproducing the WORK in the manner described above. ${ }^{11}$

Although sometimes difficult to enforce, such a letter clearly distinguishes the library's action from that of any other rights claimant. It also alerts users to the fact that the ultimate responsibility for clearing permissions for any copyright, trademark, right of publicity, or other rights interests rests with them.

\section{Semantic Considerations}

Wording in any publication policy statement needs to be crafted carefully. A copyright holder can give permission to publish because that is a designated legal, exclusive right to do so. A library's policy statement that users must obtain permission to publish from the library itself can give the appearance of interfering with the copyright holder's exclusive right to give permission. It is a semantic difference, but a potentially significant one.

Although it is clear that there is no universal awareness of this language danger zone, at least one library has moved away from use of this term in its policy statements, opting, instead, to require that users complete a Notification of Intent to Quote from or Publish original materials form. The library asserts a right to charge publication fees in its capacity as owner of the physical material but is clear to distinguish these, both in point of fact and semantically, from the copyright holder's exclusive rights. 


\section{Contracting Out Rights and Reproduction Services}

A few large, private image archives have begun offering rights and reproduction services to libraries and museums with large collections of images. These services make images available to the publishing marketplace and negotiate use fees for the library or museum while taking a fee for themselves.

There are a number of advantages to such an arrangement. An experienced image archive can market an institution's unique, and sometimes not widely known, images extensively, sometimes through a searchable Web site. A small institution with little experience or expertise in the area that fears being taken advantage of by large publishing concerns may find such an arrangement advantageous. Also, small institutions without good facilities for the quick reproduction of images may prefer outsourcing the work to an organization that will provide fast service to publishers.

There are a number of disadvantages, however. The outsourcing contractor may take a large cut of the use fees paid by a publisher for an image. In some cases, where the outsourcing contractor also has agreed to scan the images for the holding institution, the contractor may attempt to claim copyright over the electronic files produced by its scanners. Moreover, private image stock houses may not have the research institution's best interests in mind when selling rights to an image, especially in terms of the integrity of an image or its use in a distasteful way, with the institution's name attached to the image preceded by the phrase "courtesy of." Image credits in publications often carry both the contractor's name and that of the research institution, which may bother some curators.

Carefully weighing the costs, risks, and benefits of such an arrangement is absolutely necessary. Many institutions have found that negotiating with publishers is not as complex as might be expected and that receiving full fees and keeping greater control over the images is highly desirable. 
Licensing tutorials such as one created by Lesley Ellen Harris for the American Library Association ${ }^{12}$, although focused on libraries licensing the content of others, nevertheless give a good overview of the licensing process and teach negotiating skills that will serve libraries who are licensing out their own content for use by others.

Of note is the fact that a library's ability to claim copyright in librarygenerated two-dimensional photographic reproductions of public domain collection materials has come into question by the decision reached in Bridgeman Art Library Ltd. v. Corel Corp. ${ }^{13}$ in which the court ruled that photographs of original public domain works of art, though requiring talent and effort to create, were not themselves sufficiently original to merit copyright protection.

\section{Structuring a Fee Policy}

Consent to allow reproduction of images or texts of materials owned by libraries may be contingent upon the requesting party's willingness to conform to some or all of the following terms:

1. The images or texts are used for scholarly, educational, artistic, cultural, or scientific purposes which support the library's mission of the advancement of learning through research and the production of scholarly works; or for commercial purposes approved by the library.

2. The integrity of the images or texts used commercially is maintained and their use meets standards of appropriateness established by the library. Some examples of inappropriate use may be defined as: ${ }^{14}$

12. Lesley Ellen Harris, The Online Licensing Tutorial, 2002. An educational service of the American Library Association Office for Information Technology Policy and the American Association of Law Libraries.

13. 25 F.Supp.2d 421 (SD N.Y. 1999)

14. The list is derived substantially from the Permission to Publish Policy of the Huntington Library, Art Collections, and Botanical Gardens. 
- context that might be misleading or defamatory;

- alteration of the original form, meaning, or intent of the creator of the materials;

- use that would compete with or detract from an existing or planned use by the library.

3. The use of the materials in publication complies with any donor agreements attached to the materials. This will involve a careful review of such agreements.

4. The use of the materials in publication complies with copyright restrictions. This includes the stipulation that all other potential owners of copyright have been contacted, or good faith attempts have been made to do so.

5. The requester obtains and provides proper credit for the sources of images or texts used. In such a case, the library is encouraged to have a standard credit line to accompany its images.

6. The requester pays appropriate fees for publication.

\section{Structuring a Fee Schedule}

In assessing publication fees, it is advantageous to work from an established fee schedule. Appendices to this article contain sample publication fee schedules from a variety of types of institutions - an academic library, an archive, and an independent historical society. The amount that a library charges for the use of a text or an image will be at the discretion of the institution and often, where fees are determined on a case-by-case basis, at the discretion of the staff person who manages publication requests.

Factors that can influence the levels at which fees are set may include kind of use (reproduction, publication, public performance, public display, 
adaptation, advertising); intended audience; nature of the rights being requested (one-time or in perpetuity); placement of an image on the product (cover or text illustration only); size of the publisher's print run; number of versions of the product (print, video, audio, electronic editions); retail price of the product; and distribution plans (for sale or complimentary).

A pricing and licensing strategy can be viewed as a kind of soft intellectual property protection. If users feel that prices are fair and reasonably related to use, they will be less inclined to look outside legitimate distribution channels.

A library will need to consult its institution's business managers and legal counsel to ensure that a fee system does not, over time, jeopardize the institution's not-for-profit status and so that the wording of any contractual agreements is legal and precise.

\section{Negotiation and Compliance}

Compensation does not always have to take a monetary form. A successful negotiating technique can still work on the barter system. For example, a library may be willing to charge a nominal price for a first printing of a manuscript in its holdings with the understanding that if sales of the volume are successful enough to warrant additional printings, a higher licensing fee would be negotiated. A library could even make an agreement to be paid royalties, although this would require more diligence by the library in monitoring payments due.

Negotiation also may take the form of bartering for additional collection materials. Someone making a documentary film about a writer whose papers are housed in a library will want to interview individuals who had a relationship with the author, as well as look at papers and photographs in the library. A successful negotiation may take the form of a donation of 
the interviews and research material created while making the documentary in lieu of a fee for the use of materials from the library.

Although some libraries may be able to enforce publication policies by denying future use of the collections until past obligations are met, ensuring compliance in the use of library materials is admittedly difficult. Because the benefits of tracking violators is unlikely to offset the costs involved, energy is well spent on making sure patrons understand their obligations (to both the copyright holder and the owning institution) up front.

Researchers should know that if they plan to publish materials from libraries, they will be required to notify the institution in writing and place a credit line in the publication. This can be done by having them sign a form stating that they understand the policies and will abide by them before allowing them to receive reproductions of material. It should be clear that permission to publish library materials is given for a specified use or edition and new permissions will be necessary for any additional uses. Requiring a complimentary copy of the work allows the institution to check that its materials have been used only as specified and that it has received proper credit.

The proliferation of electronic media has made libraries aware that new standards may be needed for licensing electronic uses of items in their collections. Unauthorized use of collection materials is particularly difficult to control in this environment. For this reason, it is desirable to have in place policies that address preservation of the integrity of the digital information and that allow libraries to authenticate the image. Preservation of the integrity of the digital information may be accomplished by establishing a chain of custody to document the source institution and particular uses of the object. The creation of a record of use provides users with what is known about the provenance and context of digital objects so users can make informed decisions about the reliability 
and quality of the materials. A chain of custody establishing the provenance of an object helps to create the presumption that an object is authentic and has not been falsified, manipulated, or altered. The authentication process may include watermarking, fingerprinting, digital timesharing, hashing, or resolution capping of images. Licensing images becomes part of the chain of custody and is thus another way to track the use of materials.

\section{Conclusion}

Although the viewpoint of this article supports the premise that libraries have a basis for charging licensing fees, it does not argue that all institutions should or will want to charge for the scholarly or commercial use of collection materials. That is a decision for each institution to make individually. At least one library administrator has decided staff time is not well spent on any level implementing and enforcing a publication fee policy. At Yale University's Beinecke Library, although the library should be cited as the source, "it is not necessary to seek the library's permission to publish texts or images (unless the university is identified as the copyright holder)." Another director has remarked that there is little incentive for him to set up a fee policy and procedure because in his library's accounting system any revenues earned would go into a general account rather than be earmarked for special collections. Still, for those institutions considering establishing a licensing policy, this article should be helpful in crafting a rationale and corresponding fee structure. 


\section{APPENDICES}

Model fee schedules for an academic library and independent historical society, and a composite of public archives follow. It is recommended that libraries consult as models Internet-published fee schedules for the type of institution that most closely resembles their own.

\section{A. Academic Library}

\section{Publication Fee Statement and Schedule}

Statement: Publication of images of collection materials is subject to approval and fees may be charged for such use. "Publication" includes the following media: print, electronic/digital, videotape, film, or microform. Permission to use images must be obtained in advance and in writing by completing the appropriate "Notification of Intent" form. These fees are separate from any which might be assigned/assessed by the copyright holder.

The fees listed below are for non-exclusive use of a single image unless otherwise indicated. They are assessed in addition to photo duplication costs and are to be paid in advance of publication. Only those images actually used in publication are subject to these fees. If a request covers more than one form of publication, then the fees are cumulative.

Publication fees are waived for theses and dissertations.

Still Images

\section{Books: And Periodicals}

Fees

Books: Text Illustration

\begin{tabular}{lcccc}
$\begin{array}{c}\text { One-time use } \\
\text { One-language } \\
\text { One-country }\end{array}$ & $\begin{array}{c}\text { One-time use } \\
\text { One-language } \\
\text { Worldwide }\end{array}$ & $\begin{array}{c}\text { One-time use } \\
\text { All languages } \\
\text { Worldwide }\end{array}$ & $\begin{array}{c}\text { All editions } \\
\& \text { all uses }\end{array}$ \\
\hline 2,000 copies or less & $\$ 20$ & $\$ 30$ & $\$ 40$ & $\$ 50$ \\
2,001-10,000 copies & 40 & 60 & 80 & 100 \\
10,001 or more copies & 80 & 120 & 160 & 200
\end{tabular}


Books: Jacket/Cover Illustration

\begin{tabular}{lcccc}
$\begin{array}{r}\text { One-time use } \\
\text { One-language } \\
\text { One-country }\end{array}$ & $\begin{array}{c}\text { One-time use } \\
\text { One-language } \\
\text { Worldwide }\end{array}$ & $\begin{array}{c}\text { One-time use } \\
\text { All languages } \\
\text { Worldwide }\end{array}$ & $\begin{array}{c}\text { All editions } \\
\text { \& all uses }\end{array}$ \\
\hline 2,000 copies or less $\$ 100$ & $\$ 150$ & $\$ 200$ & $\$ 250$ \\
$2,001-10,000$ copies & 200 & 300 & 400 & 500 \\
10,001 or more copies 300 & 450 & 600 & 750
\end{tabular}

Periodicals: Text Illustration

$\begin{array}{lrrrr}\text { Circ. } 1,000 \text { or less } & \text { no fee } & \text { no fee } & \text { no fee } & \text { no fee } \\ \text { Circ. } 1,001-10,000 & \$ 20 & \$ 30 & \$ 40 & \$ 50 \\ \text { Circ. 10,001-99,999 } & 40 & 60 & 80 & 100 \\ \text { Circ. 100,000 or more } & 80 & 120 & 160 & 200\end{array}$

Periodicals: Jacket/Cover Illustration

$\begin{array}{lrrrr}\text { Circ. } 1,000 \text { or less } & \text { no fee } & \text { no fee } & \text { no fee } & \text { no fee } \\ \text { Circ. 1,001-10,000 } & \$ 100 & \$ 150 & \$ 200 & \$ 250 \\ \text { Circ. 10,001-99,999 } & 200 & 300 & 400 & 500 \\ \text { Circ. 100,000 or more } & 300 & 450 & 600 & 750\end{array}$

\section{Microforms and Facsimiles}

Other Print Products

\section{Fees To Be Negotiated}

\section{Fees}

Calendars, posters, greeting cards, postcards, novelty items, etc.

Printing: 1,000 or less

$\$ 200$

Printing: 1,001-9,999

300

Printing: more than 10,000

\section{Electronic Formats (editorial use) Fees}

CD-ROM, DVD, Etc. Content Illus. Packaging/Cover

2,000 copies or less

2,001-10,000 copies

10,001 or more copies
$\$ 20$

40

80
$\$ 100$

200

300

Note: Above fees are for non-exclusive, one-time, single-language, single-country rights only. Fees for additional rights are the same as those for books.

Internet / Online $\$ 100$ Per Image

\section{Television/Cable/Satellite Broadcast Fees}

One-country use, single-language only $\$ 50$ 
World use, single-language only

Note: For home video format, add $\$ 50$ per image in addition to the broadcast fees.

\section{Feature Films}

U.S. distribution

World distribution

\section{Fees}

$\$ 500$

1,000

Note: For home video format, add $\$ 100$ per image in addition to the distribution fees.

\section{Promotional Purposes}

Advertisements for television/film

Other

Moving Images

\section{Television/Cable/Satellite Broadcast}

One-country use, single-language only, minimum World use, single-language only, minimum World use, all languages, minimum

\section{Fees}

$\$ 500$

200

Note: For feature films, add $100 \%$ to above fees; for promotional purposes add $100 \%$.

\section{B. Independent Historical Society}

Copying and image licensing services are available from the Rights and Reproductions Office. Fees vary according to the kind of original material copied, the type of copy requested, and the intended use of the copy.

Reproductions of materials from the collections are provided under license agreement for purposes as indicated in writing by the user and agreed upon by the society. Conditions governing their use are specified on a contractual agreement generated by the society and to be signed both by the user and a representative of the society. Costs for reproduction of materials from the society's collections are the sum of two fees: use and production fees. The society reserves the right to require special 
fees for some forms of commercial uses. The prices listed herein are subject to change.

\section{Use Fees}

\section{Black-and-White Publication}

Black-and-white photographic reproductions for one-time, one-use, non-exclusive, single-language publication rights.

For-profit entities

Editorial use (within books, periodicals, and other published works): $\$ 75.00$

Video and film productions: $\$ 100.00$

Advertising and other non-editorial use: $\$ 250.00$ minimum

Non-profit entities

Editorial use: $\$ 25.00$

Video and film productions; $\$ 50.00$

Advertising and other non-editorial use: $\$ 125.00$

\section{Color Publication}

Color, photographic transparencies rented for a 120-day period for one-time, oneuse, non-exclusive, single-language publication rights.

For-profit entities

Editorial use (within books, periodicals, and other published works): $\$ 150.00$

Video and film productions: $\$ 200.00$

Advertising and other non-editorial use: $\$ 500.00$ minimum

Nonprofit entities

Editorial use (within books, periodicals, and other published works): $\$ 50.00$

Video and film productions: $\$ 100.00$

Advertising and other non-editorial use: $\$ 250.00$

\section{Exhibition Use}

Prints for exhibition or display purposes in museums, offices, homes, commercial organizations, schools, and other spaces.

For-profit entities: $\$ 150.00$ minimum

Non-profit entities: $\$ 25.00$

\section{Projection}

Use of slides for public lectures, classroom instruction, and business presentations.

For-profit entities: $\$ 25.00$

Non-profit entities: $\$ 5.00$ 


\section{Reference Prints}

In some instances, at the discretion of the society, reference prints are made available for research or study purposes only. Each print is stamped prominently with red ink so as to make it unsuitable for publication or display.

Reference prints: $\$ 5.00$

\section{Electronic Reproduction}

Black-and-white and color images displayed either via the Internet or in CD-ROM publications.

CD-ROM

For-profit entities: $\$ 500.00$

Non-profit entities: $\$ 250.00$

Internet use (prices are scaled, please ask for a quote)

\section{Architectural Drawings}

Full-scale reproductions on bond paper of architectural drawings, blueprints, renderings, etc.

For-profit entities: $\$ 50.00$ first sheet, $\$ 20.00$ thereafter

Non-profit entities: $\$ 20.00$ first sheet, $\$ 5.00$ thereafter

\section{Public Archive}

Ranges of commercial fees per photograph for books, serials, book jackets, posters, postcards, filmstrips, videotapes, motion picture, television, commercial display, Web pages, or similar use:
$1-5,000$ copies
$\$ 5.00-30.00$
$5,001-10,000$ copies
$\$ 20.00-50.00$
10,001-25,000 copies
$\$ 50.00-100.00$
Over 25,000 copies
$\$ 75.00-200.00$

One archive charges lower rates for in-county versus outside-county use. 


\section{Bibliography}

American Association of Museums, A Museum Guide to Copyright and

Trademark (Washington, D.C.: American Association of Museums, 1999).

Fishman, Stephen. The Public Domain: How to Find \& Use Copyright-Free Writings, Music, Art \& More (Berkeley, CA: Nolo Press, 2000).

Stephen Fishman, The Copyright Handbook: How to Protect \& Use Written Works (Berkeley, Calif.: Nolo Press).

Richard Stim, Getting Permission: How to License \& Clear Copyrighted Materials Online \& Off (Berkeley, Calif.: Nolo Press). 